\title{
Harvesting as an Alternative to Burning for Managing Spinifex Grasslands in Australia
}

\author{
Harshi K. Gamage, ${ }^{1,2}$ Paul Memmott, ${ }^{1}$ Jennifer Firn, ${ }^{3}$ and Susanne Schmidt ${ }^{2}$ \\ ${ }^{1}$ Aboriginal Environments Research Centre, School of Architecture and Institute of Social Science Research, \\ The University of Queensland, Brisbane, QLD 4072, Australia \\ ${ }^{2}$ School of Agriculture and Food Sciences, The University of Queensland, Brisbane, QLD 4072, Australia \\ ${ }^{3}$ School of Earth, Environmental and Biological Sciences, Queensland University of Technology, Brisbane, QLD 4000, Australia
}

Correspondence should be addressed to Harshi K. Gamage; h.gamage@uq.edu.au

Received 16 April 2014; Revised 5 June 2014; Accepted 16 June 2014; Published 6 July 2014

Academic Editor: Isabelle Bertrand

Copyright (C) 2014 Harshi K. Gamage et al. This is an open access article distributed under the Creative Commons Attribution License, which permits unrestricted use, distribution, and reproduction in any medium, provided the original work is properly cited.

\begin{abstract}
Sustainable harvesting of grasslands can buffer large scale wildfires and the harvested biomass can be used for various products. Spinifex (Triodia spp.) grasslands cover $\approx 30 \%$ of the Australian continent and form the dominant vegetation in the driest regions. Harvesting near settlements is being considered as a means to reduce the occurrence and intensity of wildfires and to source biomaterials for sustainable desert living. However, it is unknown if harvesting spinifex grasslands can be done sustainably without loss of biodiversity and ecosystem function. We examined the trajectory of plant regeneration of burned and harvested spinifex grassland, floristic diversity, nutrient concentrations in soil and plants, and seed germination in controlled ex situ conditions. After two to three years of burning or harvesting in dry or wet seasons, species richness, diversity, and concentrations of most nutrients in soil and leaves of regenerating spinifex plants were overall similar in burned and harvested plots. Germination tests showed that $20 \%$ of species require fire-related cues to trigger germination, indicating that fire is essential for the regeneration of some species. Further experimentation should evaluate these findings and explore if harvesting and intervention, such as sowing of fire-cued seeds, allow sustainable, localised harvesting of spinifex grasslands.
\end{abstract}

\section{Introduction}

The evergreen $\mathrm{C}_{4}$ hummock grass genus Triodia ("spinifex") forms the dominant vegetation in Australia's arid and semiarid regions, covering nearly one-third of the continent [1]. Fire is a natural disturbance in spinifex grasslands that recycles nutrients and maintains biodiversity and plant community structure $[1,2]$. Postfire native ephemeral grasses and forbs proliferate within few months but are gradually replaced by spinifex and a low cover of woody species $[3,4]$. While the effects of fire in spinifex grasslands are well known, it is unclear whether it is the removal of the dominant vegetation (spinifex) or the fire cues that trigger the seed germination that maintains plant biodiversity in these ecosystems. We examined this by comparing harvested and burned spinifex plots near settlements in north-west Queensland. If fire is not essential for maintaining plant diversity, localised harvesting could be an alternative to fire in managing spinifex grasslands. Harvested areas could act as fire breaks and plant biomass could be used as feed stock for green products [5].

Indigenous Australians have long burned and locally harvested spinifex grasslands for the purpose of hunting and obtaining materials, food, and medicine [5-8]. This practice creates small-scale mosaics of burned and unburned patches at different serial stages [9]. Such fire management no longer exists in most spinifex grasslands due to the cessation of traditional Aboriginal burning practices and has resulted in vast areas of either long unburned or burned vegetation due to wildfires $[9,10]$. The contemporary practice of patch burning in the vicinity of certain indigenous settlements buffers climate-driven variability in fire size, and the resultant mosaic of burned and unburned areas is considered vital for the integrity of spinifex grasslands [11, 12]. Land managers also use fire to increase the forage value of spinifex grasslands, prevent large-scale wildfires, diminish encroachment of woody and exotic plants, and maintain biodiversity [12-14]. 
In spinifex grasslands, the frequency, intensity, and scale of fire vary and depend on factors that include rainfall, resultant biomass accumulation, fuel moisture, and wind speed [9]. Depending on the highly variable, mean annual rainfall, it can take 3 to 30 years for spinifex to accumulate sufficient biomass to carry fire. With increasing rainfall, the rate of biomass accumulation increases, resulting in shorter fire return intervals $[1,9]$.

Due to the vast extent and remoteness of spinifex grasslands, fire management is costly, and localised harvesting near settlements could complement fire as a management tool by reintroducing the finer mosaic of vegetation patches and reducing the intensity and scale of fires. The harvested biomaterial (e.g., resin and fibre) could be used in small-scale industries in remote Australia [7]. While localised harvesting has potential benefits to local communities, undesirable effects of harvesting may include the loss of species that require fire cueing for seed germination and the removal of essential nutrients with the export of biomass. Therefore, we examined how harvesting, compared to burning, impacts on the regeneration of spinifex grasslands in north-west Queensland. Spinifex grasslands in northern Australia, including the study region, receive reliable monsoon rains in summer, resulting in shorter fire-return intervals than grasslands in central/southern regions that receive less reliable winter rains $[15,16]$. While spinifex can regenerate from seeds and burned hummock bases, other species within spinifex dominated ecosystems are not fire dependent (i.e., fire is not required for regeneration) which includes grasses (e.g., Aristida spp.) and shrubs (e.g., Rulingia loxophylla) [17]. There is surprisingly little known about the interactions of fire and regeneration of species within spinifex grasslands although different fire regimes, including interval and intensity, are likely to impact on the ability of species to regenerate.

We hypothesised that diversity of plant species and soil nutrient concentrations would be greater in burned than in harvested plots after 2-3 years due to the fire cueing and presence of ash in burned plots promoting germination and regeneration. We present the results from a field experiment that evaluated the effect of spinifex harvesting and burning in wet or dry seasons to evaluate how season affects regeneration. We tested which species required fire cueing for seed germination ex situ, since seeds can be transported across plots via wind, water, or animals and fire signals can exceed the boundaries of the experimental plots. We addressed the following questions: (i) does the floristic diversity differ in burned and harvested plots in the short term (2-3 years), (ii) is there a seasonal effect on species regeneration, (iii) does the presence of ash after fire increase nutrients in soil and subsequently in leaf tissues of spinifex, and (iv) which species require fire cues for seed germination?

\section{Methods}

2.1. Study Site. The experiment was carried out at "Wooroona paddock" ( $\left.19^{\circ} 57^{\prime} \mathrm{S}, 138^{\circ} 27^{\prime} \mathrm{E}\right)$, which forms part of a pastoral lease in north-west Queensland, $33 \mathrm{~km}$ east of Camooweal and $158 \mathrm{~km}$ west of Mt Isa in north-west Queensland. The landscape is even terrain with average elevation of
$231 \mathrm{~m}$ above sea level and reddish-brown, gravelly, and clay-sandy lithosol soils [18]. The semiarid climate has low and highly variable rainfall with a long-term annual average of $400 \mathrm{~mm}$ precipitation that mostly falls in summer (December-March). Magnitude and duration of the wet season are characterised by high interannual variation with extreme rainfalls of up to $1000 \mathrm{~mm}$ in some years. Mean annual air temperatures are 27 and $38^{\circ} \mathrm{C}$ during winter and summer, respectively [19]. The dominant vegetation in the study area is T. pungens with low open woodland of Eucalyptus leucophloia (Myrtaceae) and Acacia elachantha (Mimosaceae). Common grasses are Aristida and Sporobolus species (Poaceae) and sedges in genus Bulbostylis (Cyperaceae). Fire caused by natural lightning burned the vegetation in the study area in 2001, and the study site was lightly grazed by cattle prior to being fenced at the commencement of the experiment in 2008.

2.2. Experimental Design. The experiment was established in May 2008 at a one hectare $(100 \times 100 \mathrm{~m})$ site divided into 25 subplots of $20 \times 20 \mathrm{~m}$ and separated by a three-metrewide fire break between subplots resulting in subplot sizes of $18.5 \times 18.5 \mathrm{~m}$. Burning and harvesting treatments were implemented during dry (July 2008) and wet (March 2009) seasons. Five treatments were applied: (i) wet season harvest, (ii) wet season burn, (iii) dry season harvest, (iv) dry season burn, and (v) untreated control with intact mature vegetation dominated by spinifex. Subplots for each treatment were selected randomly with five replicates for each of the treatments. Burning involved igniting individual hummocks and spreading fire to neighbouring hummocks. The dry season harvest was performed by bobcat cutting spinifex hummocks above the base. The wet weather in March 2009 prevented vehicle access and necessitated hand harvesting with shovels that, similar to the mechanical harvesting in the dry season, removed hummocks at the base.

2.3. Floristic Survey. An expanding quadrat design with cumulative geometrical increase in subquadrat size was used for the floristic survey [20]. Eight expanding quadrats $(0.018 \times$ 0.018 to $2 \times 2 \mathrm{~m}$ ) were established at each corner of each subplot. All species, including trees and shrubs present in each subquadrat, were recorded during floristic surveys carried out in wet (April 2011) and dry (October 2011) seasons. Each quadrat was laid out on a $2 \mathrm{~m}$ diagonal from the subplot boundary to avoid edge effects, adjusting each quadrat if obstacles such as trees and termite mounds occurred in the subplots. The presence of species was recorded in each subquadrat and expressed as proportional abundance (stem counts). Visually, the regenerating spinifex $>20 \mathrm{~cm}$ diameter were recorded as resprouters, because they grow faster than seedlings due to their established root system, while plants $<20 \mathrm{~cm}$ were recorded as seedlings. Small forbs and grasses that could not be identified in the field were taken to the Queensland Herbarium for identification.

2.4. Element Composition of Soil and Leaves. In May 2010, after 2-3 years of treatment applications, soil samples were collected from three of the five replicated subplots. Within 
each subplot, soil was collected from the top $0-5 \mathrm{~cm}$ at three locations (current hummock centre, edge, and in between hummocks) within the subplot, pooled, and passed through a $2 \mathrm{~mm}$ mesh sieve. Samples were air dried for three days in the laboratory at The University of Queensland. Total carbon and nitrogen content were determined with a LECO CNS 2000 auto-analyser (LECO, St. Joseph, Michigan, USA) [21]. Total soil macronutrient concentrations ( $\mathrm{P}, \mathrm{Ca}, \mathrm{K}, \mathrm{Mg}$, and S) were determined by acid digestion and inductively coupled plasma-optical emission spectroscopy (ICPOES; Beverly, MA). Available sulphur (sulphate) was determined via calcium monophosphate extraction and ICPOES. Available cations $(\mathrm{K}, \mathrm{Ca}$, and $\mathrm{Mg}$ ) were estimated using ammonium chloride $\left(\mathrm{NH}_{4} \mathrm{Cl}\right)$ extraction and ICPOES [21]. Available soil phosphorous (inorganic P) was determined following bicarbonate extraction and colourimetric assay [22].

In May 2010, leaves were collected from spinifex in 20 subplots including mature plants in the controls and regenerating juveniles in the burned and harvested subplots. Each sample consisted of $\sim 15$ healthy mature leaves from three individual hummocks within each subplot. Samples were oven-dried at $60^{\circ} \mathrm{C}$ until a constant weight was achieved and ground to a fine powder using a ball mill. Samples were analysed for carbon and nitrogen content as described above. Another subsample of ground leaves was digested using a mixture of nitric and perchloric acids and then the concentrations of $\mathrm{P}$, $\mathrm{K}, \mathrm{Ca}$, and $\mathrm{Mg}$ were analysed via ICPOES.

2.5. Ex Situ Seed Germination. Fire cueing of seed germination was tested on 22 species which were collected during field visits to the area during wet (April) and dry (October) seasons in 2011. Only species with seeds available during this period were tested. Seeds were collected from numerous individuals of each species. Fire cues of heat, smoke, and nutrients in the ash blanket were mimicked using boiling water, $10 \%$ smoke water (derived from burned vegetation; Regen 2000 Smokemaster, Grayson, Australia), and $20 \mathrm{mM}$ $\mathrm{KNO}_{3}$ solution (see below), respectively. Smoke after fire is a key agent promoting seed germination of certain plant species in arid grasslands due to the presence of different compounds such as karrikinolide and cyanide [23]. Similarly, nitrogen containing compounds in the ash triggers seed germination of arid plant species, and we used $\mathrm{KNO}_{3}$ as a pretreatment for seeds [24].

First, seeds were sorted, chaff removed by floating on water, and dried at $25^{\circ} \mathrm{C}$ for $24 \mathrm{~h}$. Seeds were stored in plastic vials at ambient temperature $\left(25^{\circ} \mathrm{C}\right)$ for three months since many Australian species require after-ripening prior to germination. Prior to germination, seeds were placed at $35^{\circ} \mathrm{C}$ overnight since annual plants from semiarid climates often require dry hot conditions to break dormancy [25]. Twenty seeds of each species were used in three replicates per treatment. Fewer seeds $(\sim 10)$ were used for species for which only a smaller number of seeds could be collected. Seeds were sterilised by soaking in $2 \%$ sodium hypochloride solution for 2-3 min and washed thoroughly with sterilised water. For the heat treatment, seeds were soaked in boiling water for 2-3 min. For smoke, nutrients, and control treatments, seeds were imbibed in $10 \%$ smoke water, $20 \mathrm{mM} \mathrm{KNO}_{3}$, and sterilised water for $48 \mathrm{~h}$, respectively. Differing concentrations of smoke water have been used in native plant seed germination experiments [26,27]. Here, we chose concentrations of smoke water and $\mathrm{KNO}_{3}$ that had highest germination in previous experiments with spinifex [28]. Treated seeds were placed in sterile $9 \mathrm{~cm}$ Petri dishes with $1 \%$ agar as growth medium. Petri dishes were sealed with microtape and kept in a $28 \pm 1^{\circ} \mathrm{C}$ growth cabinet with $16 \mathrm{~h}$ light regime at $37 \mu \mathrm{mol} \mathrm{m}{ }^{-2} \mathrm{~s}^{-1}$. Germination was scored daily over five weeks and defined with the emergence of radicle $>3 \mathrm{~mm}$ length. We incubated seeds at $28^{\circ} \mathrm{C}$ because this temperature represents the average temperature during the rainy summer period in the study area.

2.6. Statistical Analysis. Data were analysed using Primer (version 5.2.8, Plymouth Marine Laboratory, Plymouth, England) [29] and were square root transformed to standardise prior to analysis. For floristic data, analysis of similarities (ANOSIM) was performed to compare significant differences in species composition and abundance across treatments. Species composition and abundance, across different treatment subplots, were visualised using Bray-Curtis Similarity Analysis and nonmetric multidimensional scaling (nMDS). The nMDS analysis graphically represents relationships among treatment subplots in multidimensional space. Treatment subplots that are closely clustered indicate that they are more similar in species composition and abundance than those which are further apart. The similarity percentages (SIMPER) routine in Primer was used to generate diagnostic species lists (e.g., species contributing to high or low abundance) in each treatment. This exploratory method calculates the percentage contributions from each species (relative abundance) within treatments.

We compared several surrogate measures for biodiversity including species richness $(S=$ total number of different species), Shannon-Wiener diversity index $\left(H^{\prime}\right.$; includes both number of individuals and evenness), and Pielou's evenness index ( $J^{\prime}$; how evenly individuals of each different species were distributed within each treatment) and in each treatment to see the quantitative differences (higher/lower) across treatments. We used the proportional abundance of species (stem counts recorded as out of eight expanding quadrats) in calculation of Shannon diversity indices. Significant differences of species richness, diversity, and evenness were compared across treatments using pair-wised comparisons in ANOSIM analysis. We used the following equations in calculation of diversity measures:

$$
\begin{aligned}
& \text { Species richness }(S)=\text { total number of species, } \\
& \text { Shannon diversity index }\left(H^{\prime}\right)=\sum_{i} p_{i} \log \left(p_{i}\right),
\end{aligned}
$$

where $p_{i}=$ proportional abundance of species. Consider

$$
\operatorname{Evenness}\left(J^{\prime}\right)=\frac{H^{\prime}}{H_{\max }^{\prime}},
$$

where $H_{\max }^{\prime}=$ maximum possible value of Shannon diversity. 

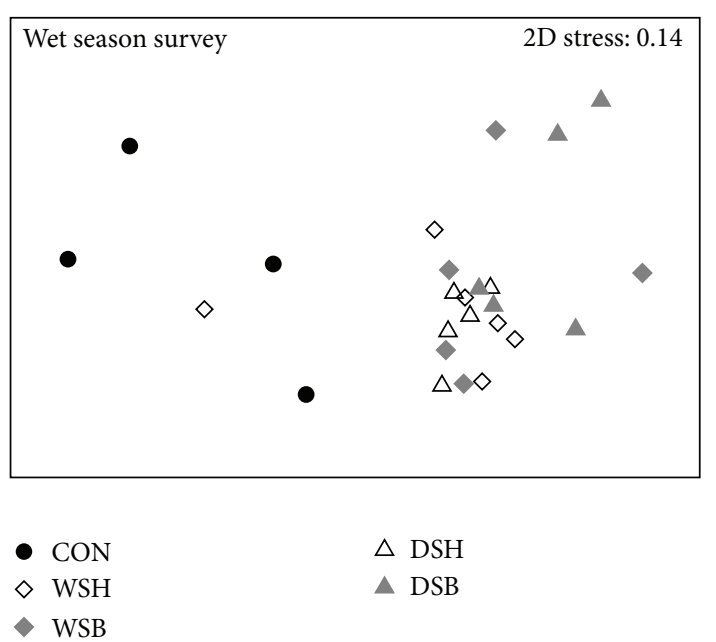

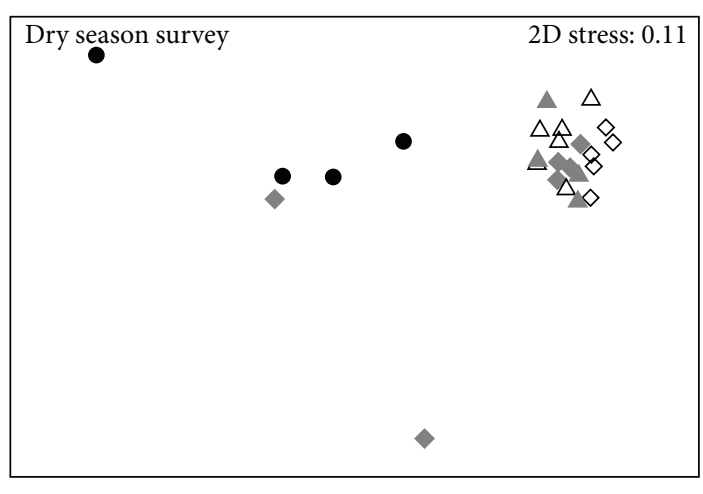

$\begin{array}{ll}\bullet \mathrm{CON} & \triangle \mathrm{DSH} \\ \diamond \mathrm{WSH} & \triangle \mathrm{DSB} \\ \diamond \mathrm{WSB} & \end{array}$

FIGURE 1: Two-dimensional nMDS ordination showing the relationship of species composition across five treatments in wet and dry season floristic surveys carried out after 2-3 years of treatment applications. Closely clustered harvested $\left(R_{d f 4}=0.397, P<0.01\right)$ and burned subplots $\left(R_{d f 4}=0.404, P<0.01\right)$ differ significantly from the control subplots. Control $=\mathrm{CON}$, wet season harvest $=$ WSH, wet season burn $=$ WSB, dry season harvest $=\mathrm{DSH}$, and dry season burn $=\mathrm{DSB}$.

Element and ex situ seed germination data across differing treatment plots were analysed using ANOSIM. Pair-wised comparisons in ANISOM analysis determined the significant differences among treatment plots.

\section{Results}

3.1. Floristics. Analysis of similarities (ANOSIM) on floristic surveys showed significant differences in community structure across treatments in wet $\left(R_{d f 4}=0.397, P<0.01\right)$ and dry season $(R=0.404, P<0.01)$ floristic surveys. Visualising in two-dimensional ordinations of nonmetric multidimensional scaling (nMDS) with Bray-Curtis similarity measure showed that the control treatment was significantly different from harvested and burned treatments in wet and dry seasons (Figure 1). However, wet and dry season harvested and burned subplots were clustered closely (Figure 1). Species richness and diversity were significantly lower in the controls than burned and harvested treatments in wet and dry season surveys 2-3 years after treatment implementations (Figure 2). The distribution of individuals of different species (Evenness) was similar across treatments (Figure 2).

We identified 71 species in 17 families in floristic surveys during wet and dry season (April and October 2011) in burned and harvested plots, and of those, 42 species were recorded in wet and dry seasons, 22 in wet season only, and 7 in dry season only (Supplement A (see Supplementary Material available online at http://dx.doi.org/10.1155/2014/430431)). Spinifex regenerated from seeds as well as from burned and harvested hummock bases and had the highest abundance (resprouters and seedlings were combined) across all treatments in wet and dry season floristic surveys 2-3 years after treatment (Table 1). Resprouting spinifex (diameter $>20 \mathrm{~cm}$ ) had a greater abundance than seedlings (diameter $<20 \mathrm{~cm}$ ) across burned and harvested subplots in wet and dry season surveys (Table 1). Similarity percentage (SIMPER) analysis on species composition showed that across all treatments Bulbostylis barbata and Enneapogon polyphyllus were second and third highest in abundance, respectively, with the exception of the control treatment (Table 1). In the control, Bulbostylis barbata and Pterocaulon serrulatum, and Bulbostylis barbata and Eriachne armitii were the second and third highest in abundance in wet and dry season surveys, respectively. In wet and dry season surveys, Paspalidium rarum was found only in the wet season harvested treatment while Eragrostis cumingii and Perotis rara were recorded in the wet season harvested treatment during the wet season survey. Tripogon loliiformis was recorded only in the wet season burned treatment in the wet season survey while the occurrence of Abutilon otocarpum was restricted to the wet season harvest treatment during the dry season survey (Table 1).

3.2. Element Composition of Soil and Spinifex Leaves. Analysis of similarities showed treatment effect on some of the measured soil elements (global $R$ statistics $=0.538, P<0.01$ ) when sampled after two years of treatment application. The global $R$ statistic value indicates similarity or dissimilarity of replicates within a site. The global $R$ statistics varies from 1 to 0 and if $R=1$, then all replicates within sites are similar in the measured variables [29]. Since we found global $R=0.538$ for soil nutrients, we further compared the soil nutrients across the treatments. Total soil Ca $\left(R_{d f 4}=0.416\right.$, $P<0.01)$ and $\mathrm{Mg}$ contents $(R=0.332, P<0.05)$ differed significantly across treatments. Total Ca was higher in control than burned and harvested treatments while total $\mathrm{Mg}$ was lowest in the dry season harvest treatment but similar across the other treatments (Table 2). Similar to soil nutrients, there was a treatment effect on plant biomass nutrients of mature and regenerating $T$. pungens (global $R$ statistics $=0.187$, $P<0.05)$. Consistent with soil nutrients, leaf $\mathrm{Ca}$ and $\mathrm{Mg}$ levels varied across treatments (Table 2$)$. Leaf $\mathrm{Ca}\left(R_{d f 4}=\right.$ 0.349, $P<0.05)$ and $\mathrm{Mg}(R=0.287, P<0.05)$ were 

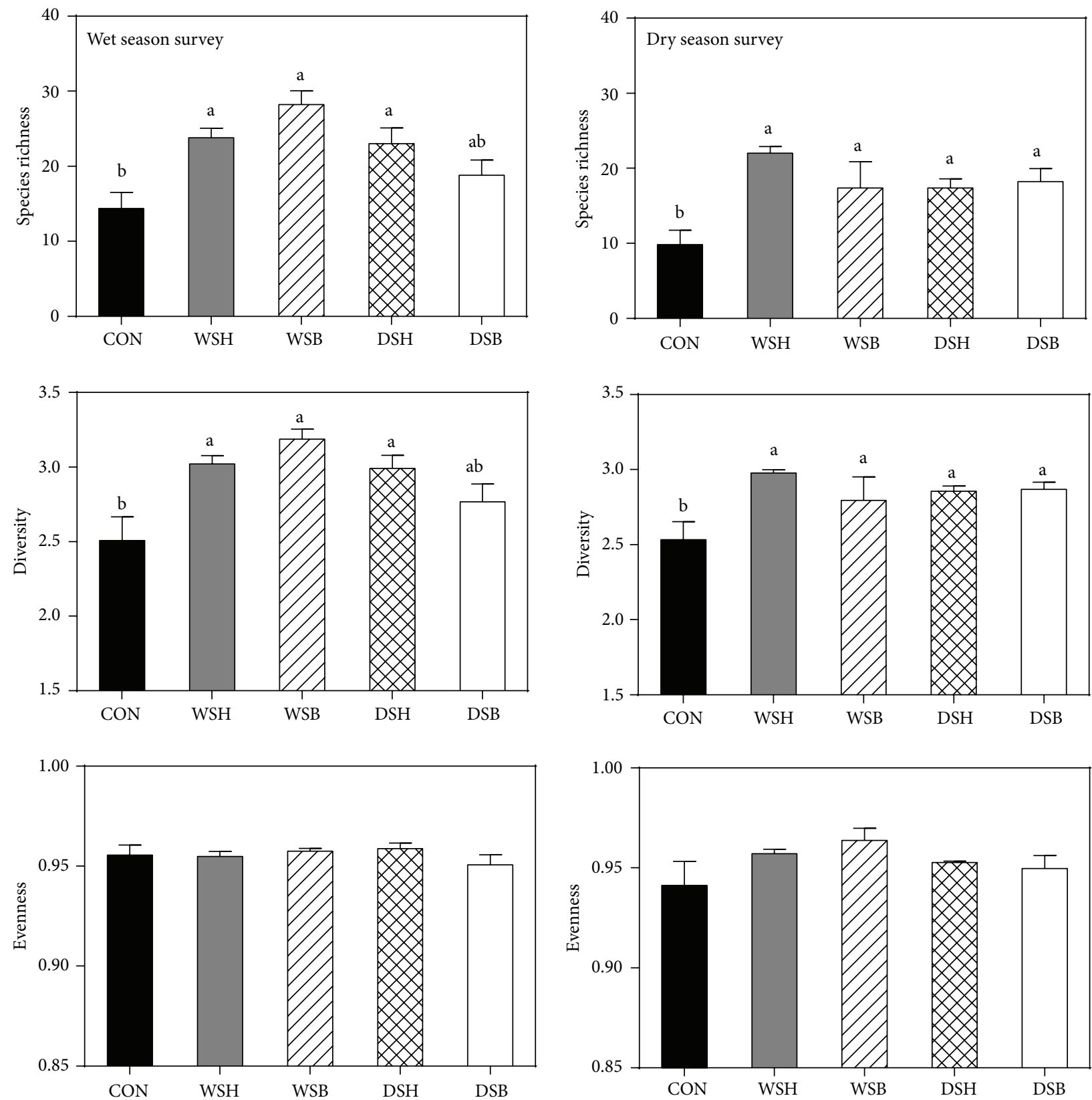

FIGURE 2: Species richness (number of species), Shannon diversity (number of species and individuals), and evenness (distribution of individuals of each species) across treatments carried out after 2-3 years of treatment applications. Different letters within each panel indicate significant differences between treatments $(P<0.05)$. Bars represent means of five replicates and standard errors. Control $=\mathrm{CON}$, wet season harvest $=\mathrm{WSH}$, wet season burn $=\mathrm{WSB}$, dry season harvest $=\mathrm{DSH}$, and dry season burn $=\mathrm{DSB}$.

greater in mature hummocks of the control plots than all other treatments (Table 2).

3.3. Ex Situ Seed Germination. Of the 22 species tested, only one species (Maireana villosa) did not germinate in any of the applied treatments (smoke water, $\mathrm{KNO}_{3}$, boiling water, and control) and this species was excluded from further analysis. Four species (Acacia elachantha, Bonamia media, Gossypium australe, and Hibiscus sturtii) only germinated with a fire cue while the other 17 species germinated in the control treatment. Seeds of all species with the exception of
Enneapogon polyphyllus and Sporobolus mitchellii had a strong germination response when treated with a fire cue compared to the control. Woody species such as Acacia species, Bonamia media, Gossypium australe, Hibiscus sturtii, and Senna notabilis were more strongly represented in the group of species requiring fire cues than grass species (Figure 3 ).

Acacia species ( $A$. adsurgens and A. elachantha) and Senna notabilis had the highest germination rate (90-93\%) when treated with boiling water, while germination of Ptilotus exaltatus was highest (93\%) with $\mathrm{KNO}_{3}$ (Figure 3). Pterocaulon serrulatum had $>50 \%$ seed germination across all 


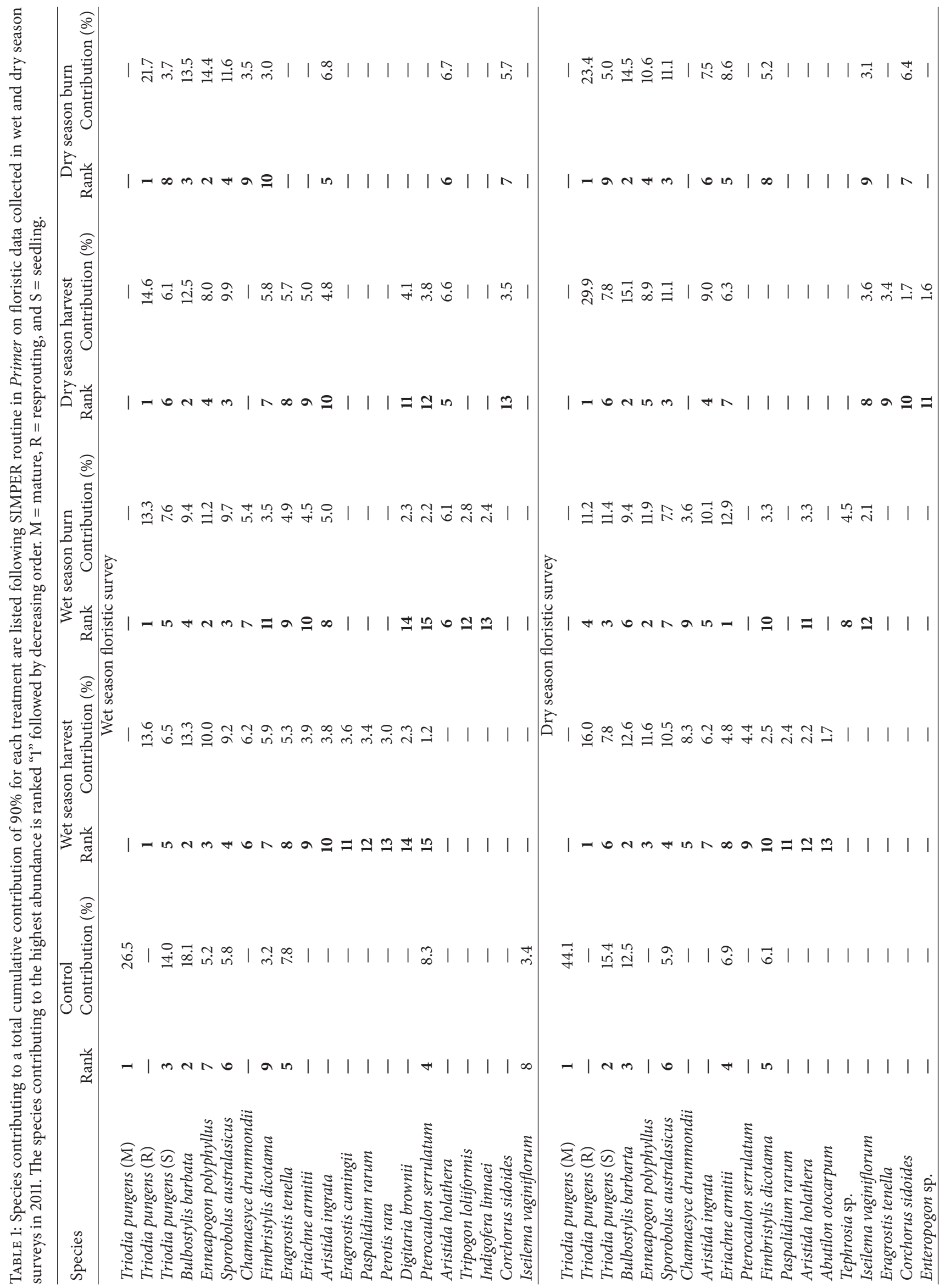


TABLE 2: Summary of soil (total and extractable) and leaf nutrients of Triodia pungens in control and treatments. Results are mean values with standard errors. Means followed by different letters are significantly different $(P<0.05)$ across treatments.

\begin{tabular}{|c|c|c|c|c|c|}
\hline & Control & Wet season harvest & Wet season burn & Dry season harvest & Dry season burn \\
\hline \multicolumn{6}{|c|}{ Soil $\mathrm{C}$ and nutrients $\left(\mathrm{mg} \mathrm{g}^{-1}\right)$} \\
\hline Total C & $12 \pm 0.30$ & $15 \pm 1.1$ & $13 \pm 1.0$ & $14 \pm 1.2$ & $15 \pm 0.5$ \\
\hline Total N & $1.8 \pm 0.01$ & $2.0 \pm 0.01$ & $1.7 \pm 0.01$ & $2.0 \pm 0.01$ & $2.0 \pm 0.01$ \\
\hline Total P & $0.3 \pm 0.04$ & $0.3 \pm 0.02$ & $0.2 \pm 0.01$ & $0.2 \pm 0.01$ & $0.2 \pm 0.02$ \\
\hline Ext. P & $0.01 \pm 0.00$ & $0.02 \pm 0.00$ & $0.01 \pm 0.00$ & $0.01 \pm 0.00$ & $0.01 \pm 0.00$ \\
\hline Total K & $2.3 \pm 0.11$ & $2.2 \pm 0.63$ & $2.9 \pm 0.27$ & $2.2 \pm 0.12$ & $2.3 \pm 0.07$ \\
\hline Ext. K & $0.1 \pm 0.01$ & $0.1 \pm 0.01$ & $0.1 \pm 0.01$ & $0.1 \pm 0.02$ & $0.1 \pm 0.01$ \\
\hline Total Ca & $0.3 \pm 0.04^{\mathrm{a}}$ & $0.2 \pm 0.03^{\mathrm{ab}}$ & $0.15 \pm 0.01^{b}$ & $0.12 \pm 0.01^{\mathrm{b}}$ & $0.16 \pm 0.01^{\mathrm{b}}$ \\
\hline Ext. Ca & $0.1 \pm 0.02$ & $0.2 \pm 0.03$ & $0.1 \pm 0.01$ & $0.1 \pm 0.01$ & $0.2 \pm 0.03$ \\
\hline Total Mg & $0.2 \pm 0.02^{\mathrm{a}}$ & $0.2 \pm 0.05^{\mathrm{a}}$ & $0.2 \pm 0.01^{\mathrm{a}}$ & $0.1 \pm 0.01^{b}$ & $0.2 \pm 0.01^{\mathrm{a}}$ \\
\hline Ext. Mg & $0.05 \pm 0.01$ & $0.05 \pm 0.00$ & $0.04 \pm 0.00$ & $0.04 \pm 0.00$ & $0.04 \pm 0.01$ \\
\hline Total S & $0.9 \pm 0.08$ & $1.2 \pm 0.05$ & $0.8 \pm 0.05$ & $1.2 \pm 0.09$ & $0.9 \pm 0.03$ \\
\hline Ext. S & $0.01 \pm 0.00$ & $0.01 \pm 0.00$ & $0.01 \pm 0.00$ & $0.01 \pm 0.00$ & $0.01 \pm 0.00$ \\
\hline \multicolumn{6}{|c|}{ Leaf $\mathrm{C}$ and nutrients $\left(\mathrm{mg} \mathrm{g}^{-1}\right)$} \\
\hline $\mathrm{C}$ & $442 \pm 3.4$ & $445 \pm 1.5$ & $446 \pm 0.07$ & $442 \pm 3.3$ & $448 \pm 2.9$ \\
\hline $\mathrm{N}$ & $8.2 \pm 0.02$ & $9.8 \pm 0.03$ & $9.4 \pm 0.04$ & $9.1 \pm 0.03$ & $8.7 \pm 0.02$ \\
\hline $\mathrm{P}$ & $0.5 \pm 0.01$ & $0.5 \pm 0.01$ & $0.5 \pm 0.01$ & $0.4 \pm 0.01$ & $0.5 \pm 0.00$ \\
\hline $\mathrm{K}$ & $9.2 \pm 0.34$ & $8.6 \pm 0.39$ & $8.4 \pm 0.28$ & $8.8 \pm 0.27$ & $9.0 \pm 0.29$ \\
\hline $\mathrm{Ca}$ & $3.7 \pm 0.30^{\mathrm{a}}$ & $2.2 \pm 0.09^{b}$ & $2.5 \pm 0.09^{b}$ & $2.7 \pm 0.07^{\mathrm{b}}$ & $2.6 \pm 0.16^{\mathrm{b}}$ \\
\hline $\mathrm{Mg}$ & $1.8 \pm 0.03$ & $1.4 \pm 0.02$ & $1.6 \pm 0.03$ & $1.4 \pm 0.03$ & $1.5 \pm 0.02$ \\
\hline S & $1.6 \pm 0.02$ & $1.3 \pm 0.06$ & $1.3 \pm 0.09$ & $1.3 \pm 0.03$ & $1.3 \pm 0.02$ \\
\hline
\end{tabular}

treatments with the exception of the boiling water treatment which prevented germination. Among grasses, Aristida ingrata germinated well (50-80\%) across all the treatments and in the control, while Triodia pungens was highest (60\%) in the smoke water treatment. Most species geminated rapidly and within the first week of the experiment. Across all species, germination rate ranked as $\mathrm{KNO}_{3}>$ boiling water $>$ control > smoke water.

\section{Discussion}

4.1. Diversity of Regenerating Species Is Unaffected by Treatment or Season of Treatment. Low intensity and frequency of disturbances including fire, grazing, or other means of removing plant biomass are considered essential to maintain species diversity in natural grasslands $[1,30,31]$ and most seedling recruitment arises from a previously dormant soil seed bank after fire [32]. Consistent with this notion, we detected greater floristic diversity in burned or harvested treatments than in the control after 2-3 years of burning or harvesting in wet or dry season. Overall, we observed no differences in species richness and diversity between harvested and burned treatments, and individuals of different species had an even distribution across treatments. This finding is similar to a study showing that, 16 months after harvesting or burning of T. basedowii grasslands in central Australia, some of the dominant species had similar regeneration diversity across treatments [17]. Likewise, burned versus mowed tallgrass prairies in North America had comparable plant species diversity after three years of treatment applications [33].
In our study, the observed increase in plant regeneration diversity after the removal of spinifex biomass via harvesting or burning is likely to be due well-established root systems that enable access to resources more efficiently than germinants. Thereby, mature spinifex reduces availability of water and nutrients (and possibly light) for the germinants. [34, 35]. Allelopathic effects may also play a role but have not been studied systematically in spinifex grasslands. For example, seed germination and establishment of obligate seeder species Triodia sp. nov. in Kimberley, Western Australia, are inhibited by autotoxicity which results in lower seed establishment in areas with mature spinifex present compared with areas where mature plants were removed by fire or harvesting [36].

We found that some species regenerated only after a wet season burn (Tripogon loliiformis) or after harvest (Abutilon otocarpum, Eragrostis cumingii, Paspalidium rarum, and Perotis rara), indicating that timing and type of disturbance affect the regeneration of species differently. While soil temperature and moisture, and possibly the soil seed bank, are likely to differ in wet and dry seasons and affect regeneration, soil moisture is the most limiting factor for seed germination and establishment in arid environments [37]. Our ex situ seed germination experiment showed that 17 out of 22 species germinated without pretreatment which confirms that seeds of most species germinate in the absence of fire if water is available. We did not evaluate if species germinated in harvested plots in the following wet season.

Despite the overall similar species diversity between fire and harvest treatments, our study showed that some species required fire triggers for germination. Ex situ germination 

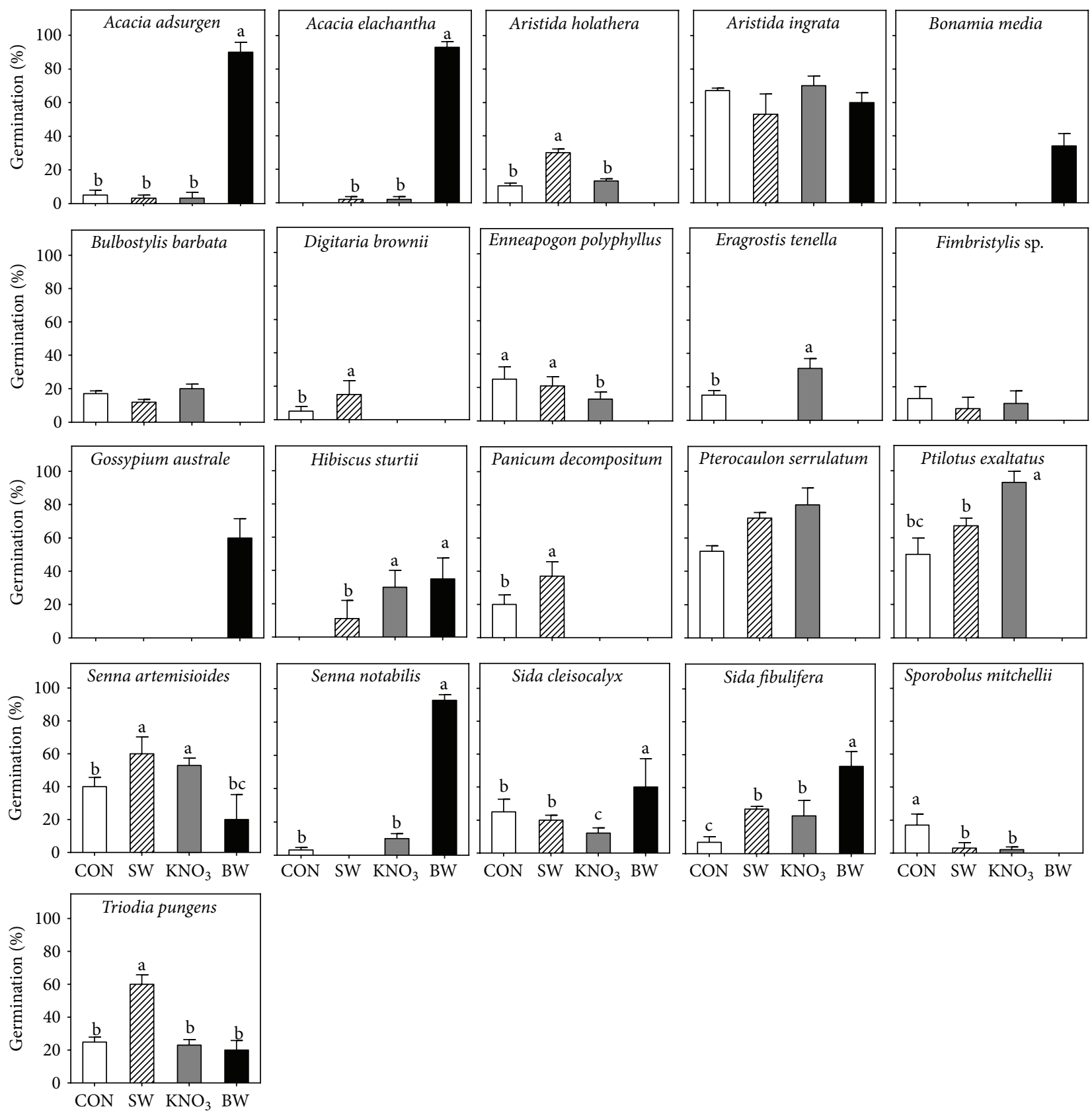

$\mathrm{CON}$ : control

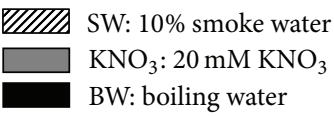

FIGURE 3: Ex situ seed germination rate (\%) of 21 species pretreated with $10 \%$ smoke water, $20 \mathrm{mM}$ potassium nitrate or boiling water, and control (sterile water) for $48 \mathrm{~h}$. Seeds were incubated at $28 \pm 1^{\circ} \mathrm{C}$ temperature with $16 \mathrm{~h}$ light for five weeks. Bars represent means of three replicates and standard errors. Different letters represent significant differences across treatments at $P<0.05$ within each species.

of Acacia species, Bonamia media, Gossypium australe, and Senna notabilis demonstrated that heat is required to induce germination. Acacia adsurgens and A. elachantha had a $>95 \%$ germination rate after treatment with boiling water, and $<10 \%$ of seeds germinated in control, smoke water, and $\mathrm{KNO}_{3}$ treatments, confirming that heat is required for species with thick seed coats, consistent with previous studies [38]. Similarly, Senna pleurocarpa regenerated in burned but not in harvested spinifex (T. basedowii) grasslands in central Australia [17]. However, in our study, species that were heat stimulated in ex situ tests occurred in low abundance in the burned treatments, which points to a low presence of viable seeds. 
Another consideration is that, in addition to fire, microbial activity, fluctuating soil temperatures, and scarification by movement on the soil surface aid the breakdown of seed coats [38]. We found that grasses and sedges did not require fire cueing for germination. Rather, these species are likely to respond to favourable moisture and temperature regimes. For some of the studied plant families, ex situ germination was consistent with the floristic composition in the field. For example, Poaceae accounted for most of the regenerating species and had the highest number of individuals irrespective of treatment, indicating that species in the Poaceae family are prevalent in the seed bank and germinate readily without an apparent need for fire cues.

While fire cues are essential to trigger germination of some species, intense fires could be lethal for small-seeded species with thinner seed coats and may prevent their regeneration, such as Digitaria brownii, Eragrostis tenella, Panicum decompositum (Poaceae) and Bulbostylis barbata, and Fimbristylis sp. (Cyperaceae) that did not germinate in the ex situ heat treatments. Yet, some of these species (Bulbostylis barbata and Fimbristylis sp.) were recorded in plots burnt in wet or dry seasons. A possible explanation is that temperatures in the burned plots were lower than those in our ex situ tests. Indeed, [39] showed that after fire temperatures decrease at soil depths of 1,2 , and $3 \mathrm{~cm}$ from 125 and 67 to $40^{\circ} \mathrm{C}$, respectively, in central Australian spinifex grassland.

Despite the observed effects of ex situ treatments on seed germination of several of the studied species, regeneration was similar in burned and harvested treatments. Harvesting and burning in the dry season may allow regeneration of forbs and grasses in the following wet season at the cost of other species. It is also possible that, in our study area, species richness and diversity peak in the first year following disturbance due to the presence of ephemeral grasses and forbs and perennials with different life spans. Indeed, in $e x$ situ tests, $>50 \%$ of the species germinated within a week. Spinifex regenerates from seeds and burned hummock bases $[24,40]$, as well as from harvested hummocks (T. pungens in our study and T. basedowii) [41]. We conclude that, at least 23 years after disturbance, removal of spinifex biomass triggers regeneration of T. pungens and germination of the majority of species that characterise the postfire plant community.

4.2. Burning Does Not Increase Nutrient Availability in the Short Term. We hypothesised that due to the addition of ash after fire, burning rather than harvesting of T. pungens results in increased nutrient availability in soil and in the plant biomass of regenerating vegetation. Contrary to predictions, we observed no consistent effects of burning and harvesting on nutrients relations of soil or plant biomass when sampling 2-3 years of treatment applications. However, three months after fire at a site close to our study area, nutrient levels were elevated after fire in the top $5 \mathrm{~cm}$ of soil (\%C $1.68 \pm 0.1 \mathrm{SE}$ and $1.18 \pm 0.1$ burned-unburned, resp.; $\% \mathrm{~N} 0.11 \pm 0.005$ and $0.07 \pm 0.007, \% \mathrm{P} 0.035 \pm 0.003$ and $0.029 \pm 0.001$, with available P $15.7 \pm 1.3$ and $11.7 \pm 0.7 \mathrm{mg} / \mathrm{kg}^{-1}$ dry soil; unpublished data). It appears that the increase in soil nutrients after fire in spinifex grasslands is short-lived.
While nutrient levels in soil and plant biomass were overall similar in harvested and burned plots, a higher calcium content in soil and spinifex biomass characterised the control plots. The reasons for higher calcium levels are unclear. Calcium may have been derived from decomposing litter in control plots, but burning generally leads to increased calcium and other cations in soil due to ash deposit [42]. Such effects may have been masked due to erosion or winnowing effects in our study because nutrients were not analysed immediately after fire. Whether harvesting alters nutrient relations in the longer term when compared with the effects of fire remains to be established.

Arid zone plants have to maintain adequate concentrations of foliar nutrients to sustain life functions, with leaf $\mathrm{N}$ and $\mathrm{P}$ contents of 15 and $2 \mathrm{mgg}^{-1}$ leaf dry weight being considered minimum requirements for plants [43]. In our study, leaves of mature T. pungens had very low $\mathrm{N}$ and $\mathrm{P}$ contents of $\sim 8$ and $\sim 0.5 \mathrm{mg} \mathrm{g}^{-1}$, respectively, while other macronutrients $(\mathrm{Ca}, \mathrm{Mg}, \mathrm{K}$, and $\mathrm{S}$ ) were in a similar range as reported for other arid zone species [43] (Table 2). Similarly, mature T. schinzii and T. basedowii in the Great Sandy Desert, Western Australia, had low N and P contents of 4 and $0.25 \mathrm{mg} \mathrm{g}^{-1}$, respectively [44]; and T. schinzii and T. pungens had $\mathrm{N}$ : $\mathrm{P}$ ratios of $16: 1$ and $T$. basedowii $30: 1$. This suggests that $\mathrm{P}$, rather than $\mathrm{N}$, is the most limiting nutrient in the T. pungens grasslands as $\mathrm{N}: \mathrm{P}$ ratios $>16: 1$ are considered indicative of P limitation [45]. Low foliar P concentrations are however not unusual for Australian vegetation and are an adaptation to low-P soils [46].

4.3. Alternative Fire-Harvest Cycles for Sustainable Management of Spinifex Grasslands. Wildfires management in spinifex grasslands, especially after high rainfall years that promote above average biomass accumulation, is essential for avoiding large-scale wild fires. Extended periods of high rainfall can result in large fires within 1-3 years in northern Australian regions that receive reliable monsoonal rainfalls (G. Armstrong, Charles Darwin University, personnel communication). In addition, the predicted effects of global climate change on arid biomes include higher net primary productivity enabled by greater water use efficiency as a result of rising atmospheric $\mathrm{CO}_{2}$ concentrations [47]. In prairie, the combined increases in temperature and atmospheric $\mathrm{CO}_{2}$ concentration stimulated biomass accumulation to a greater extent in grasses with the $\mathrm{C}_{4}$ pathway of photosynthesis than $\mathrm{C}_{3}$ grasses [48]. Similar to other $\mathrm{C}_{4}$ species, spinifex may respond to elevated atmospheric $\mathrm{CO}_{2}$ with increased growth that in turn would increase fire frequency and intensity, but this has not yet been investigated [49].

Fire recycles and nutrients contained in mature spinifex hummocks [3] break the dormancy of fire-cued seeds [16]. However, the obligate seeder species may not persist in spinifex grasslands if fires occur in high frequency and intensity [50]. Managing spinifex grasslands at small scales with alternating fire-harvesting cycles may ensure their longterm ecological integrity, including constraining encroachment of shrubs and trees. Species that require fire cues for seed germination will regenerate in burned areas and it 
should be examined if dispersal of fire cued seeds occurs in neighbouring harvested areas. Harvesting with shovels or hand-held motorised devices is feasible at small scales and would minimise soil compaction and impact on wildlife. The effects of differing harvesting techniques need to be established.

\section{Conclusions}

Our study compared the plant regeneration diversity of burned and harvested spinifex-dominated grassland in semiarid Australia. Addressing our initial question whether localised harvesting of spinifex is feasible, we conclude that while the study provides some answers, continued longerterm monitoring of species regeneration after harvesting and burning has to evaluate whether the responses observed here can be generalised across the spinifex grasslands in Australia. While removing the mature vegetation of spinifex allowed the regeneration of most species, the species which require fire cues for germination may disappear if fire is excluded from spinifex grasslands and change the floristic composition. Further, harvesting spinifex could impact on animals that depend on spinifex communities for habitats and food sources [41] and the effects on fauna should be included in future research. We currently have no predictive ability for the impact of increasing atmospheric $\mathrm{CO}_{2}$ concentrations and other environmental changes on spinifex growth, but harvesting near settlements could reinstate the finer mosaic of vegetation patches creating a protective buffer against intense wildfires while providing biomaterial for remote community industries. Overall, managing spinifex grasslands by harvesting may help to ensure long-term ecological integrity as well as generate biomaterials. Research is underway evaluating the practicality of manual versus mechanised harvesting and uses of spinifex biomass for a range of applications.

\section{Conflict of Interests}

The authors declare that there is no conflict of interests regarding the publication of this paper.

\section{Acknowledgments}

The research was enabled with an Australian Research Council Discovery Grant (DP0877161 to Paul Memmott and Susanne Schmidt). The authors thank the Dugalunji Aboriginal Corporation and Myuma Pty Ltd., Camooweal, for collaboration and assistance with establishment and maintenance of the field experiment. They thank Dr. Boyd Wright for help with floristic surveys and Dr. Jitka Kochanek for advice on seed germination. They also thank the staff at Queensland and Alice Spring Herbaria for assistance with species identification.

\section{References}

[1] G. E. Allan and R. I. Southgate, "Fire regimes in the Spinifex landscapes of Australia," in Flammable Australia: The Fire Regimes and Biodiversity of a Continent, R. A. Bradstock, J.
E. Williams, and M. A. Gill, Eds., pp. 145-176, Cambridge University Press, Cambridge, UK, 2002.

[2] J. S. Beard, “The vegetation of the Australian arid zone," in Arid Australia, H. G. Cogger and E. E. Cameron, Eds., pp. 113-117, Australian Museum, Sydney, Australia, 1984.

[3] G. F. Griffin, "Will it burn-should it burn? Management of the Spinifex grasslands of inland Australia," in Desertified Grasslands, G. P. Chapman, Ed., pp. 63-76, Academic Press, London, UK, 1990.

[4] B. R. Wright and P. J. Clarke, "Fire regime (recency, interval and season) changes the composition of spinifex (Triodia spp.)dominated desert dunes," Australian Journal of Botany, vol. 55, no. 7, pp. 709-724, 2007.

[5] H. K. Gamage, S. Mondal, L. A. Wallis et al., "Indigenous and modern biomaterials derived from Triodia ("spinifex") grasslands in Australia," Australian Journal of Botany, vol. 60, no. 2, pp. 114-127, 2012.

[6] P. Memmott and C. Go-Sam, "Spinifex houses of the western desert," in Gunyah Goondie and Wurley: The Aboriginal Architecture of Australia, P. Memmott, Ed., pp. 208-231, University of Queensland Press, St Lucia, Australia, 2007.

[7] H. T. Pitman and L. A. Wallis, "The point of spinifex: aboriginal uses of spinifex grasses in Australia," Ethnobotany Research and Applications, vol. 10, pp. 109-131, 2012.

[8] O. Powell, R. J. Fensham, and P. Memmott, "Indigenous Use of Spinifex Resin for Hafting in North-Eastern Australia," Economic Botany, vol. 20, pp. 1-15, 2013.

[9] N. D. Burrows, B. Ward, and A. Robinson, "Fuel dynamics and fire spread in Spinifex grasslands of the Western desert," Proceedings of the Royal Society of Queensland, vol. 115, pp. 6976, 2009.

[10] N. D. Burrows and P. E. S. Christensen, "A survey of aboriginal fire patterns in the Western Desert of Western Australia," in Proceedings of the International Symposium on Fire and the Environment: Ecological and Cultural Perspectives, S. C. Nodvin and T. A. Waldrop, Eds., pp. 297-305, USDA Southeastern Forest Experiment Station, Asheville, NC, USA, March 1991.

[11] R. Bliege Bird, D. W. Bird, B. F. Codding, C. H. Parker, and J. H. Jones, "The "fire stick farming" hypothesis: australian Aboriginal foraging strategies, biodiversity, and anthropogenic fire mosaics," Proceedings of the National Academy of Sciences of the United States of America, vol. 105, no. 39, pp. 14796-14801, 2008.

[12] R. B. Bird, B. F. Codding, P. G. Kauhanen, and D. W. Bird, "Aboriginal hunting buffers climate-driven fire-size variability in Australia's spinifex grasslands," Proceedings of the National Academy of Sciences of the United States of America, vol. 109, no. 26, pp. 10287-10292, 2012.

[13] A. B. Craig, "Fire management of rangelands in the kimberley low-rainfall zone: a review," Rangeland Journal, vol. 21, no. 1, pp. 39-70, 1999.

[14] G. P. Edwards, G. E. Allan, C. Brock, A. Duguid, K. Gabrys, and P. Vaarzon-Morel, "Fire and its management in central Australia," The Rangeland Journal, vol. 30, no. 1, pp. 109-121, 2008.

[15] B. Rice and M. Westoby, "Regeneration after fire in Spinifex R. Br.," Australian Journal of Ecology, vol. 24, pp. 563-572, 1999.

[16] A. N. Andersen, G. D. Cook, L. K. Corbett et al., "Fire frequency and biodiversity conservation in Australian tropical savannas: Implications from the Kapalga fire experiment," Austral Ecology, vol. 30, no. 2, pp. 155-167, 2005. 
[17] M. McNellie, "Vegetation regeneration after spinifex harvesting and burning at Ayers Rock Resort, Yulara," Unpublished Report, Biodiversity Unit, Parks and Wildlife Commission, Northern Territory, 2000.

[18] R. F. Isbell, The Australian Soil Classification, CSIRO Publishing, Collingwood, Victoria, Australia, 1996.

[19] BOM, "Bureau of Meteorology," http://www.bom.gov.au/.

[20] R. G. Uys, W. J. Bond, and T. M. Everson, "The effect of different fire regimes on plant diversity in southern African grasslands," Biological Conservation, vol. 118, no. 4, pp. 489-499, 2004.

[21] G. E. Rayment and D. J. Lyons, Soil Chemical Methods: Australasia, CSIRO, Collingwood, Victoria, Australia, 2011.

[22] G. E. Rayment and F. R. Higginson, Australian Laboratory Handbook of Soil and Water Chemical Methods, Inkata Press, Melbourne, Australia, 1992.

[23] G. R. Flematti, D. J. Merritt, M. J. Piggott et al., "Burning vegetation produces cyanohydrins that liberate cyanide and stimulate seed germination," Nature Communications, vol. 2, no. 1, article 360, 2011.

[24] G. B. Wells, Biology and restoration ecology of spinifex grasses (Plectrachne and Spinifex spp.) with special reference to the Argyle diamond mines, Western Australia [Ph.D. thesis], University of Western Australia, Perth, Australia, 1999.

[25] G. L. Hoyle, M. I. Daws, K. J. Steadman, and S. W. Adkins, "Pre- and post-harvest influences on physiological dormancy alleviation of an Australian Asteraceae species: Actinobole uliginosum (A. Gray) H. Eichler," Seed Science Research, vol. 18, no. 4, pp. 191-199, 2008.

[26] K. W. Dixon, S. Roche, and J. S. Pate, “The promotive effect of smoke derived from burnt native vegetation on seed germination of Western Australian plants," Oecologia, vol. 101, no. 2, pp. 185-192, 1995.

[27] S. W. Adkins and N. C. B. Peters, "Smoke derived from burnt vegetation stimulates germination of arable weeds," Seed Science Research, vol. 11, no. 3, pp. 213-222, 2001.

[28] G. B. Neave, Regeneration of spinifex (Spinifex spp.) grasslands after burning or harvesting [Honours thesis], University of Queensland, St Lucia, Australia, 2010.

[29] K. R. Clarke and R. M. Warwick, PRIMER Version 5.2.8, PRIMER-E, Plymouth Marine Laboratory, Plymouth, UK, 2nd edition, 2001.

[30] W. J. Bond, F. I. Woodward, and G. F. Midgley, "The global distribution of ecosystems in a world without fire," New Phytologist, vol. 165, no. 2, pp. 525-538, 2005.

[31] G. E. Overbeck, S. C. Müller, V. D. Pillar, and J. Pfadenhauer, "Fine-scale post-fire dynamics in southern Brazilian subtropical grassland," Journal of Vegetation Science, vol. 16, no. 6, pp. 655664, 2005.

[32] J. E. Kinloch and M. H. Friedel, "Soil seed reserves in arid grazing lands of central Australia-part 1: seed bank and vegetation dynamics," Journal of Arid Environments, vol. 60, no. 1, pp. 133-161, 2005.

[33] F. V. Dyke, S. E. V. Kley, C. E. Page, and J. G. V. Beek, "Restoration efforts for plant and bird communities in tallgrass prairies using prescribed burning and mowing," Restoration Ecology, vol. 12, no. 4, pp. 575-585, 2004.

[34] D. M. J. S. Bowman, “Tansley Review No. 101. The impact of Aboriginal landscape burning on the Australian biota," New Phytologist, vol. 140, no. 3, pp. 385-410, 1998.

[35] D. W. Bird, R. B. Bird, and C. H. Parker, "Aboriginal burning regimes and hunting strategies in Australia's Western Desert," Human Ecology, vol. 33, no. 4, pp. 443-464, 2005.
[36] G. Armstrong and S. Legge, "The post-fire response of an obligate seeding Triodia species (Poaceae) in the fire-prone Kimberley, north-west Australia," International Journal of Wildland Fire, vol. 20, no. 8, pp. 974-981, 2011.

[37] D. T. Bell, "The process of germination in Australian species," Australian Journal of Botany, vol. 47, no. 4, pp. 475-517, 1999.

[38] E. Jurado and M. Westoby, "Germination biology of selected central Australian plants," Australian Journal of Ecology, vol. 17, no. 3, pp. 341-348, 1992.

[39] B. R. Wright and P. J. Clarke, "Relationships between soil temperatures and properties of fire in feathertop spinifex (Triodia schinzii (Henrard) Lazarides) sandridge desert in central Australia," The Rangeland Journal, vol. 30, no. 3, pp. 317-325, 2008.

[40] G. Armstrong, “Triodia caelestialis (Triodieae: Chloridoideae: Poaceae), a new species from the central Kimberley, Western Australia," Journal of the Royal Society of Western Australia, vol. 91, no. 4, pp. 313-317, 2008.

[41] P. Masters, C. R. Dickman, and M. Crowther, "Effects of cover reduction on mulgara Dasycercus cristicauda (Marsupialia: Dasyuridae), rodent and invertebrate populations in central Australia: implications for land management," Austral Ecology, vol. 28, no. 6, pp. 658-665, 2003.

[42] R. J. Raison, "Modification of the soil environment by vegetation fires, with particular reference to nitrogen transformations: a review," Plant and Soil, vol. 51, no. 1, pp. 73-108, 1979.

[43] E. Epstein and A. J. Bloom, Mineral Nutrition of Plants: Principles and Perspectives, Sinauer Accociates, Sunderland, Mass, USA, 2nd edition, 2005.

[44] A. M. Grigg, E. J. Veneklaas, and H. Lambers, "Water relations and mineral nutrition of Triodia grasses on desert dunes and interdunes," Australian Journal of Botany, vol. 56, no. 5, pp. 408421, 2008.

[45] W. Koerselman and A. F. M. Meuleman, "The vegetation N:P ratio: a new tool to detect the nature of nutrient limitation," Journal of Applied Ecology, vol. 33, no. 6, pp. 1441-1450, 1996.

[46] H. Lambers, G. R. Cawthray, P. Giavalisco et al., "Proteaceae from severely phosphorus-impoverished soils extensively replace phospholipids with galactolipids and sulfolipids during leaf development to achieve a high photosynthetic phosphorususe-efficiency," New Phytologist, vol. 196, no. 4, pp. 1098-1108, 2012.

[47] J. M. Craine, T. W. Ocheltree, J. B. Nippert et al., "Global diversity of drought tolerance and grassland climate-change resilience," Nature Climate Change, vol. 3, no. 1, pp. 63-67, 2013.

[48] J. A. Morgan, D. R. Lecain, E. Pendall et al., " $\mathrm{C}_{4}$ grasses prosper as carbon dioxide eliminates desiccation in warmed semi-arid grassland," Nature, vol. 476, no. 7359, pp. 202-205, 2011.

[49] L. Hughes, "Climate change and Australia: trends, projections and impacts," Austral Ecology, vol. 28, no. 4, pp. 423-443, 2003.

[50] G. Armstrong and B. Phillips, "Fire history from life-history: determining the fire regime that a plant community is adapted using life-histories," PLoS ONE, vol. 7, no. 2, Article ID e31544, 2012. 

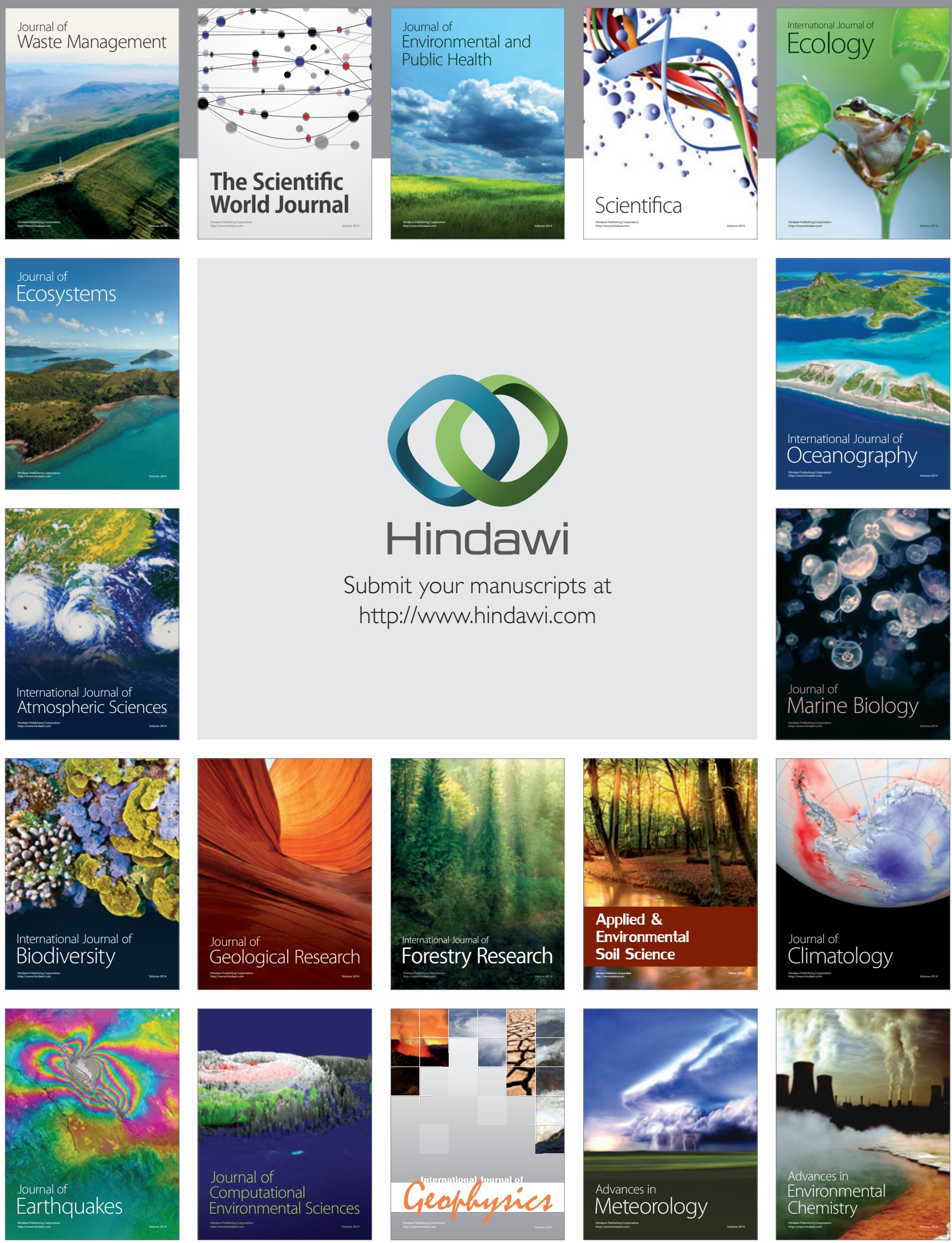